\title{
Development of Morotai Island-North Maluku based on oceanographic-ecosystem condition
}

\author{
Noir P. Purba ${ }^{1,3}$; Heti Herawati ${ }^{2}$; Lantun P. Dewanti²; Ibnu Faizal ${ }^{1,3}$; \\ Izza M. Apriliani²; Marine K. Martasuganda ${ }^{3}$ \\ ${ }^{1)}$ Marine Research Laboratory (MEAL), Universitas Padjadjaran, Indonesia \\ 2) Fisheries and Management Technology Laboratory, Universitas Padjadjaran, Indonesia \\ 3) Departement of Marine Science, Universitas Padjadjaran, Indonesia \\ *To whom correspondence should be addressed. E-mail: noir.purba@ unpad.ac.id
}

\begin{abstract}
Morotai Island is developing district located in the North of North Halmahera and one of the areas that has potential source from ecosystem biodiversity. This biodiversity is very unique related to ocean condition such as ocean currents and other properties. This research used survey data in 2015 and other data from satellite and database insitu. The results showed that the Sea Surface Temperature (SST) ranges from $26.7{ }^{\circ} \mathrm{C}$ to $32.8{ }^{\circ} \mathrm{C}$ and the salinity ranges from 33.48 to 36.8 psu characterized by open ocean. The ocean currents patterns different in surrounding area due to variety of depth, tide effect, monsoonal situation, and local aspects. The mangrove area mostly located in the south, while coral reef stands in the almost coastal area. This region is mostly influenced by monsoons and also the Indonesia throughflow. From the results, the location in the southern part is very suitable for marine culture and tourism, while in the northern region it is very suitable for tourism, conservancy, and fishing. These activities will lead Morotai as an important area for enhancing the local revenue.
\end{abstract}

Keywords: Coastal management, Indonesia throughflow, Marine activity, Monsoon, North Halmahera

JEL Classsification: Q56, Q58

\section{INTRODUCTION}

Indonesia seas have a high diversity of ecosystem, renewable and non-renewable natural resources, which have provided numerous impact for increasing economic, social, and cultural sustainable (Nurkholis, Nuryadin, Syaifudin, Handika, Setyobudi \& Udjianto 2015). The high biodiversity in Indonesia due to the unique archipelago position related to Asian and Australia terrestrial and two oceans.

One of area has unique ecosystem and ocean system is Morotai Island. The island is a part of North Maluku Province located in North Halmahera. This island is a strategic area in the northeast of Indonesia. These regions have rich water nutrients due to existence of Indonesia Throughflow (ITF) (Purba \& Pranowo, 2015). Ocean circulation that comes from Pacific transferred high nutrients and trapped in the south of the islands due to currents retroflection around these islands. Nutrients are very important for marine ecosystem and biota to grow. These two aspects (oceanographic condition and ecosystems) as main aspect for Marine Spatial Planning (MSP). MSP or sea zoning as guidance to industries, government, and other stakeholder to invest in specific area. In this case, Ministry 
of Fishery and Marine Affairs (MMAF) already surveyed environments condition of Morotai since 2009.

Several scientists have done observed the correlation between oceanographic and ecosystem condition related to marine zoning. Purba, Pangestu, Mulyani \& Fadhillah (2018), explained the challenge to acquire Biawak Island based on Oceanographic condition. Simanjorang, Pranowo, Sari, Purba \& Syamsuddin (2018), used oceanographic database to build marine ecoregion. Nurhayati (2006) has observed around Morotai Island and found the pattern of salinity, temperature, and ocean currents. In tropic waters, differences of Sea Surface Temperature (SST) within the year is quite small. The temperature in Indonesia around $26.5^{\circ}-32^{\circ} \mathrm{C}$ (Nugraha, Purba, Junianto \& Sunarto, 2018). Water mass in Morotai Islands also affected by local water masses and global circulation from the Pacific (Haikal, Taofiqurohman \& Riyantini, 2012).

Scientific study needed in oceanography and ecosystems for development of Morotai Islands. This paper described the coral reef, mangroves, and seagrass ecosystems conditions and distribution need to find out along oceanographic parameters to determined conditions of Morotai Island suitable for conservation, tourism, and fisheries. Reflecting these challenges, this research aims to describe the potential economic sectors based on ecosystem, fisheries biodiversity, and oceanographic.

\section{DATA AND METHOD}

\section{Geographic locations}

The area embedded from $2^{\circ} 00^{\prime \prime}$ to $2^{\circ} 40^{\prime \prime} \mathrm{N}$ and $128^{\circ} 15^{\prime \prime}$ to $128^{\circ} 48^{\prime \prime}$ E. Bathymetry profile averages 0-1000 meters with deepest depth in east of the island. Around small islands in the southwest of the main island, depth of water less than 200 meters which consist of 0-20 m (shallow waters) (KKP, 2015). The Morotai islands District experiences a rainy and dry season and is highly influenced by tropical monsoon seasons.

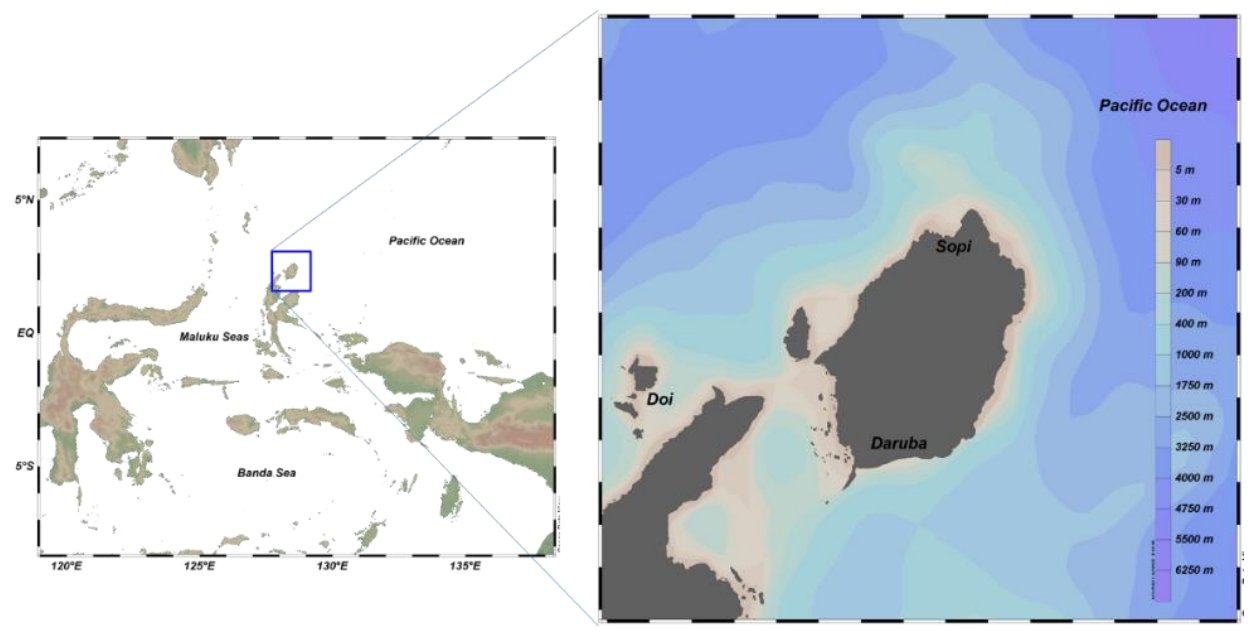

Figure 1. The geographic location of Morotai island with bathymetry Source: GEBCO; Schiltzer, 2018

Morotai Island consists of around 33 small islands and borders with Pacific Oceans to the north and east of islands, the Halmahera Sea on Southeast, Morotai Strait on South, and Sulawesi Sea on West. The area surrounding Morotai also known as Alur Lintas Kepulauan Indonesia (ALKI) from north to south. This water influenced by Indonesia Throughflow (ITF) and also by monsoon wind that blows periodically (Haikal, 
Taofiqurohman, \& Riyantini, 2012). The smallest island located in the southwest of the main island.

\section{Data profiles}

In 2015, MMAF did the primary survey to describe the condition of terrestrial and ocean condition for zoning plan. For this purpose, data collected included Sea Surface Temperature (SST), salinity, ocean currents, and water quality. These parameters measured by portable instruments and laboratory analysis. Secondary data from a various source are using such as from National Oceanographic Data Centre (NODC) for salinity and sea surface temperature. Wind data monthly collected from the European Centre for Medium-Range Weather Forecasts (ECMWF). For ecosystem conditions, survey of mangrove and seagrass used quadrat transects and coral reef via manta taw surveyed. To support the analysis, literature from online searching also used. For fishery activities, the result was done by questionnaire and in-situ survey. This research used descriptive analysis and combined oceanographic conditions and ecosystem profiles as a basis to analyze the locations and potential economic.

\section{RESULTS AND DISCUSSION}

\section{Oceanographic condition}

Generally, in all regions, wind speed has range 2.2 to $8.8 \mathrm{~m} / \mathrm{s}$ with dominant direction to the west. Maximum speed of wind occurred during January, which is west monsoon, which is also affected surface current that moves to the west (Figure 1). Minimum speed of wind happens in May, directed to the east. East of Indonesia especially Morotai islands also affected by westward wind from Pacific, monsoons, El Nino situation (Purba \& Pranowo, 2015).

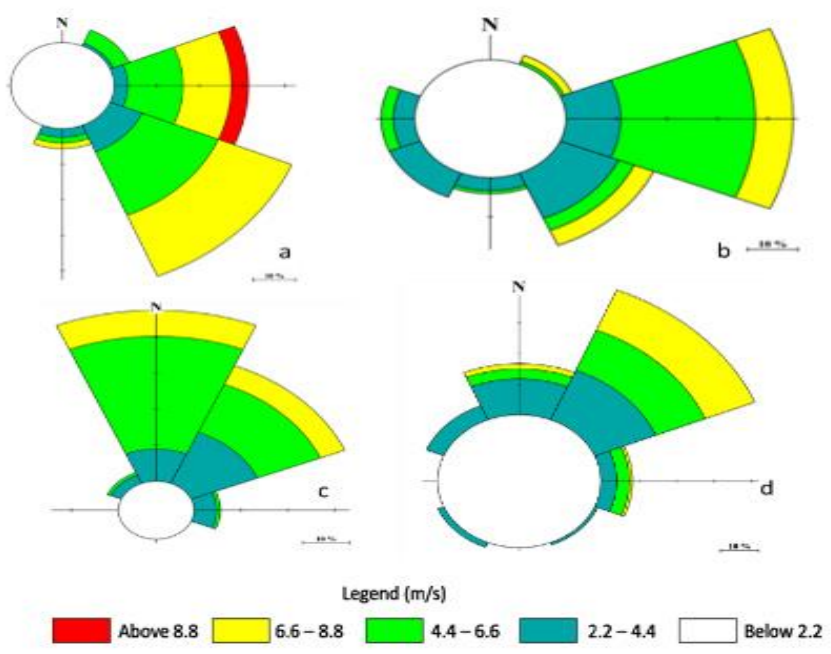

Figure 1. Wind condition during monsoons,

Notes: a) Dec-Jan-Feb, b) Mar-Apr-May, c) Jun-Jul-Aug, d) Sep-Oct-Nov

Source: ECMWF

In general, with interaction between monsoon and surface water, the velocity of water range from $0.5-1.5 \mathrm{~m} / \mathrm{s}$. In the shallow waters (south and southwest) the currents dominantly to south-east. Moreover, in the west side, ocean currents move from south to north parallel to coastline. Furthermore, pattern of currents surrounding Morotai Island not only affected by monsoon and ITF, but also by tides especially in Rao Straits. 
SST is one of parameter used to identify the fishing ground and thermal stress for ecosystem to growth. $\mathrm{P}_{2} \mathrm{O}$ LIPI (2006) found that SST around $29.0-30.1{ }^{\circ} \mathrm{C}$ in 14 stations around these islands. The values were similar to data in 2007 which was around $29,72-30,51^{\circ} \mathrm{C}$, and the averages was around $30,12 \pm 0,255^{\circ} \mathrm{C}$ (Figure 2). In 2015, it was measured between $26.7-32.8^{\circ} \mathrm{C}$. The high temperature in 2015 caused by El Nino that drift WPWP (Western Pacific Warm Pool). SST in Morotai Island affected by tropical water mass in the Pacific Ocean that passes Indonesia to Indian Oceans. SST also affected by local currents, wind pattern, and tides. The type of water mass is similar to a warm pool in west tropical Pacific Oceans.

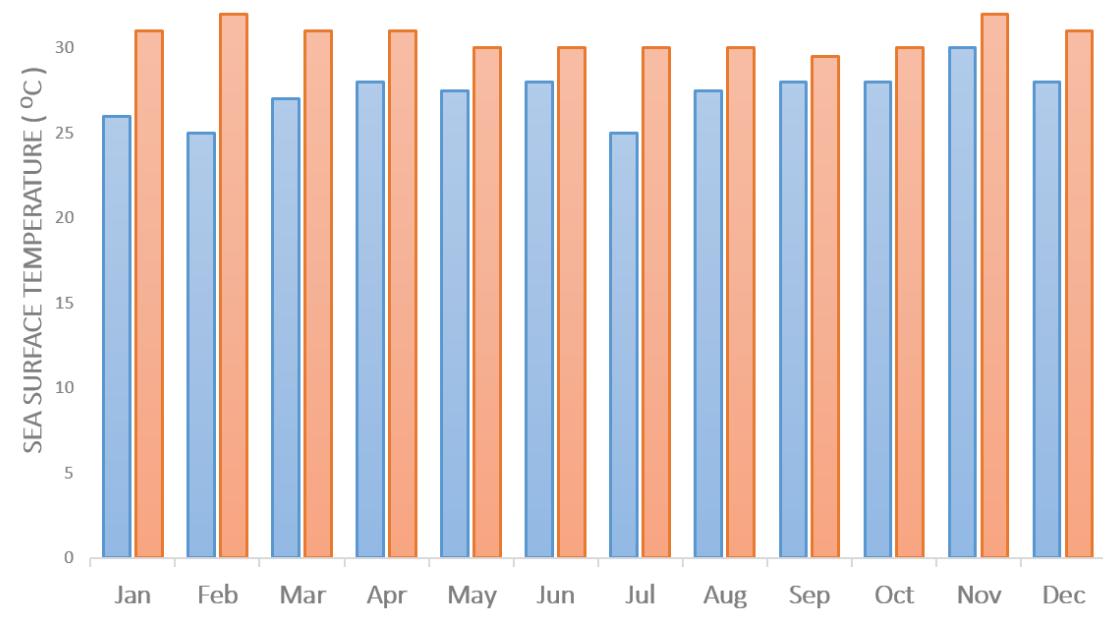

Figure 2. SST each month in a year (Minimun-Maximum).

Source: NODC and in-situ survey in 2015

SST conditions that close to the mainland rather high and less to open sea. This phenomenal related to bathymetry in that area. In shallow waters (around mainland) profile of bedload is slope, more high temperature than deep waters area (far from the mainland). The similar result found by (Nurhayati, 2006; Lana, Kurniawati, Purba \& Syamsuddin, 2017) mentioned that the thermocline layer between 100-150 m.

The average value of salinity was around 33.48 PSU and, in some locations, reached 36.8 PSU characterized by the open ocean from the Pacific Ocean. Although many rivers are in the east of the Island, these conditions do not and reduce the value of salinity because the water discharge from the river is not large. Horizontal distribution of salinity in the sea waters west and south (southwest), based on the results of several previous studies, shows increasing salinity by increasing the distance from the coast of this island towards the open sea. On the coast of Morotai Islands salinity ranges from 31-33 PSU and increases to around 34 PSU with increasing distance towards the sea. In some river estuaries on the coast of this island, the salinity is relatively lower compared to other parts. There are many flowing rivers to the east, but relatively small so that at high tide they will enter deep into the waters. This will also cause a salinity value that shows a value of around 27.9 PSU (almost the same as sea water). As for Zoning Planning, the salinity value is still suitable for marine culture, especially in the south and Southwest regions.

\section{Ecosystem biodiversity}

There are three main ecosystems in shallow waters such as coral reef, mangroves, and seagrass. Coral reef ccosystems are widespread in small islands mostly located in the southwest and around Morotai Island (Figure 3). Mangroves and seagrass also found 
around small islands and the south west coast which is flat and muddy. The trapped currents in south and south-west side also bring high nutrients to coastal area where the habitat of ecosystems.

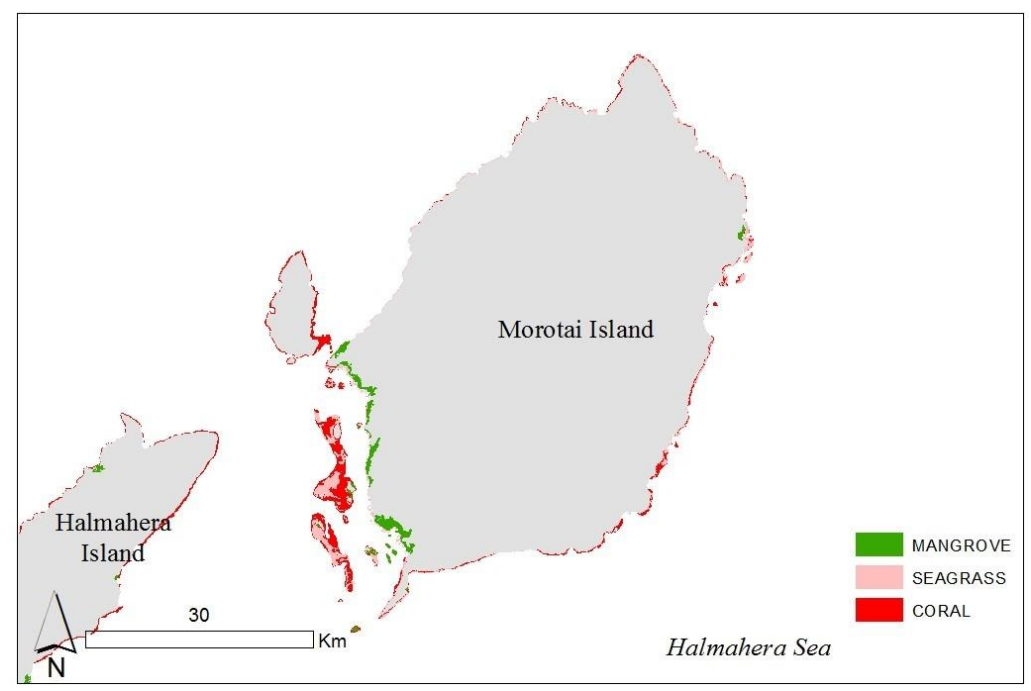

Figure 3. Shallow water ecosystem

Source: Insitu data and satellite imaginery

Coral conditions ranged from moderate (with a cover of $30 \%$ ) to good (50\%). The distribution of coral reef ecosystems is almost evenly distributed in several coastal waters and small islands. The massive coral and foliose coral species dominate coral cover at the observation location with a percentage of $8.69 \%$. The abundance of fish in the observation location is worth 1.16 with the number of fish counted as many as 1624 at 20 observation stations with different amounts for each station. Comparison of coral and reef fish conditions above, most of the observation stations have coral conditions which are included in the medium category and in reef fish shows that most of the stations belong to the good category. Aorrelation that occurs between coral reefs and reef fish shows that the correlation that occurs is positive, which means that good coral conditions will have a good effect on the abundance of reef fishes (Figure 4).

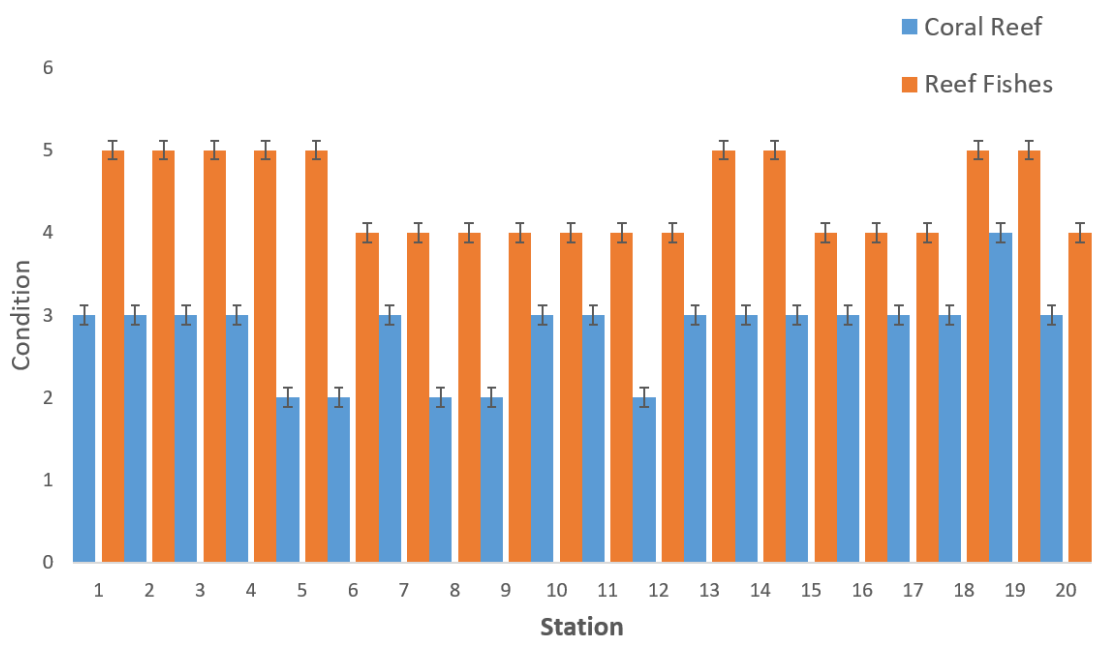

Figure 4. Coral reefs and reef fishes conditions Notes: 1) Very Bad; 2)Bad; 3)Moderate; 4)Good; 5)Very Good Source: MMAF survey in 2015 
In general, these mangroves are found in the form of a broad population. The types of mangroves or mangroves found consisted of the types of Sesuvium portulacastrum, Lumnitzera racemosa, Terminalia cattapa, Scaevola taccada, Lythraceae Phempis, Hibiscus tiliaceus, Xylocarpus granatum, X. moluccensis, Aegiceras corniculatum. Ahmad (2005) also found Osbornia octodonta, Pandanus tectorius, Pongamia pinnata, Bruguiera gymnorhiza, Ceriops tagal, Rhizophora apiculata, R. mucronata, R. stylosa, Sonneratia alba, Heritiera littoralis in south Morotai. The density of mangrove cover is in the range of 1800-2000 trees/ha, especially very high on small islands in the waters south west and the coastal area of Morotai Island from Wayabula to Daruba.

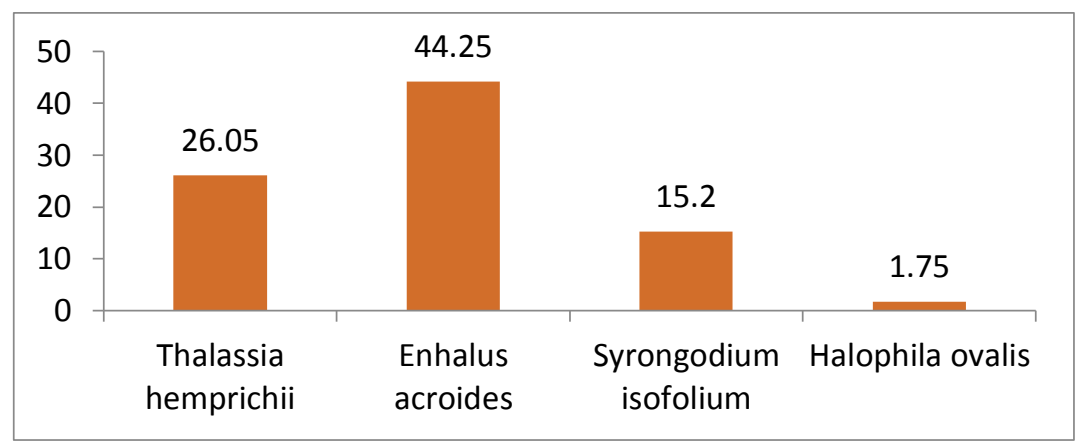

Figure 5. Seagrass type density

Source: MMAF survey in 2015

Seagrasses are found in four types and three types of the Hydrocharitaceae family, namely Enhalus acoroides, Thalassia hemprichii and Halophila ovalis. One type of Cymodoceaceae family is Syringodium isoetifolium. In the small islands scattered in the south and southwest of Morotai Island, four seagrass species were found with the largest to the smallest seagrass stands, respectively, Thalassia hemprichii, Enhalus acoroides, Halophila ovalis and Syringodium isoetifolium, while in the southern coastal areas west coast of Morotai Island, only one species of seagrass was found, Enhalus acoroides with $30-80 \%$ cover. In the northern area, the percentage of cover up to $100 \%$ was found in Sangowo Village, which consisted of seagrass types, Thalassia hemprichii and Syrongodium isofolium.

\section{Fishery profiles}

Fisheries is one of the marine economic activities in North Maluku Province and becomes "Prime movers" because of it is considerable contribution to fisheries and marine products in general. The standing stock potential in North Maluku waters is estimate to reach 694382.48 tons with a maximum sustainable yield of 347,191.24 tons/year consisting of large pelagic fish of 211,590.00 tons/year and demersal fish 135,005.24 tons/year. There is also an increasing trend from capture fisheries from 2011-2013, from 9,434 tons to 16,198 tons which is equal to $58 \%$. Data from MMAF (2019), showed that fishery production in from 2017 to 2019 increase from 1580 tons 1793 ton in 2017. Moreover, estimation of potential fish resources 4 mile 61.167 units based on 2015-2017 data.

One of the main fish standing is tuna and become the largest catch compared to other species with 10,884 tons in 2013 , followed by flying fish, other pelagic fish. Furthermore, the production of demersal fish commodities of 2,325 tons. From this potential estimate shows that the potential of North Maluku's water resources is prospective to be managed and utilized sustainably. Some areas that can be used as areas for developing marine culture such as minapolitan area in the south, south-west as the core area (Minapolis), as well as North Morotai, Morotai Jaya, East Morotai as a buffer zone (hinterland). The leading commodities developed are seaweed and grouper. For fish commodities such as snapper also has a fairly high production value of 1.12 tons. 

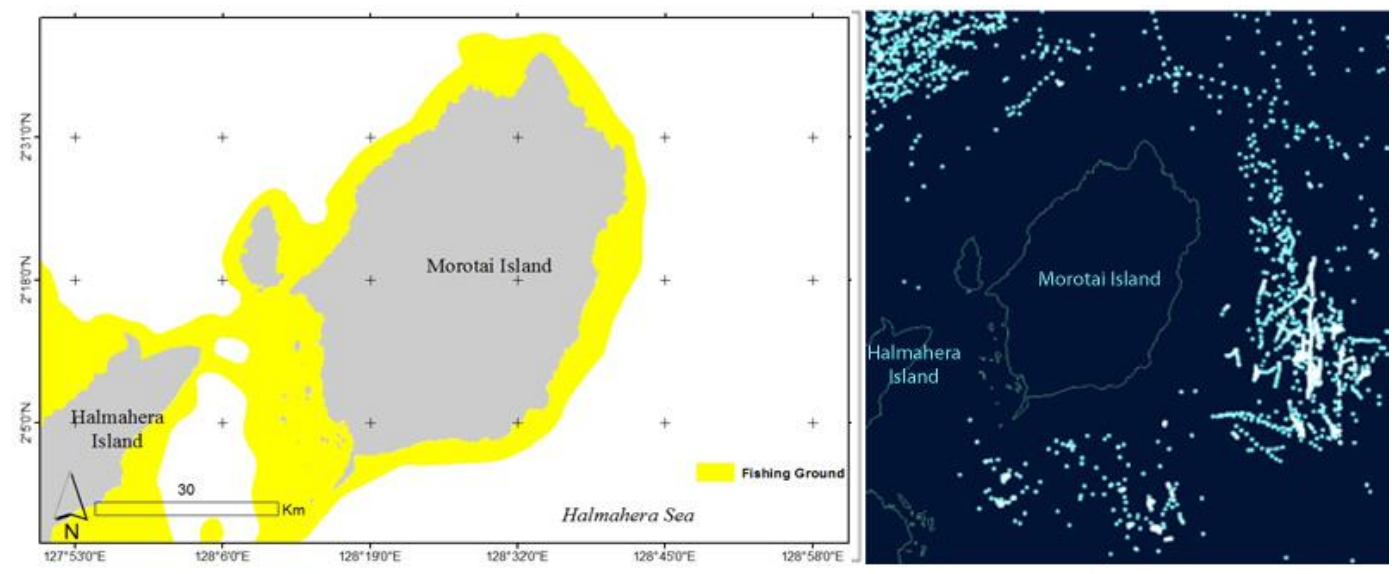

Figure 6. Fishing ground area around Morotai, (left) 4 mil waters, (right) catch area outside Morotai, with data from global fishing watch snapshot.

Source: Satellite imaginary and Global Fishing Watch.

Some commodities Aquaculture in this region is a superior commodity, among others, North Maluku waters are very potential for seaweed cultivation where the area of cultivation is estimated at 10,000 ha. The new potential is used as much as 500 tons/year and is an extract-making material so the investment opportunity for making extracts is potential activities. Aquaculture development using a sustainable cultivation system, such as development using floating net cages and embedded net cages.

\section{Development and challenges}

Based on oceanographic and ecosystem conditions, the development in Morotai Islands divided into several parts. In the south, especially around the small islands, the conditions of the waters are calm with nutrient rich, more suitable for marine tourism and marine culture (Figure 7). In the eastern part of the islands, it is established as offshore fishing. For the northern region, it is more suitable for special water tourism such as surfing, marine defense, and special marine area.
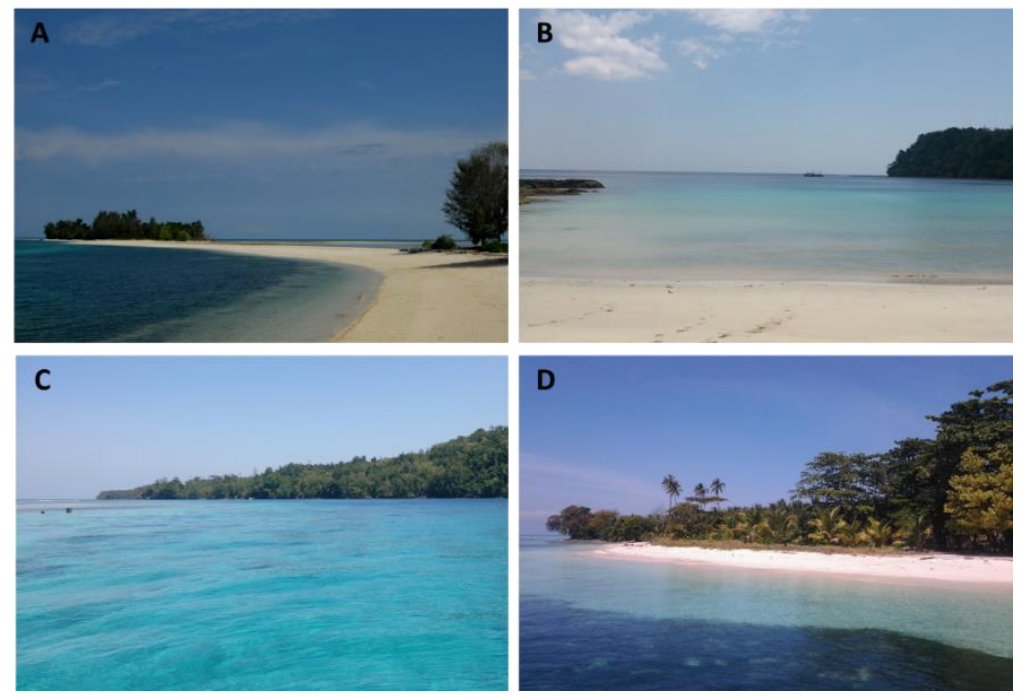

Figure 7. Strategic locations for tourists development in Morotai Islands

Notes: A) Dodola island, B) Tanjung Gorango, C) Rao island, D) Kokoya island.

Source: In-situ survey in 2015

These regions are currently being built and some of them have been carried out by infrastructure development and made into Special Economic Zones (Kawasan Ekonomi 
Khusus/KEK) by government. KEK which is located on north Morotai Island, North Maluku Province is stipulated through Government Regulation No. 50 of 2014 with an area of 1,101.76 hectares (DKEK, 2018). Due to the potential of biodiversity and ocean condition, the potential area located in 31 locations, whereas 21 locations located in south of the island. Some of potential area describes in Table 1.

Table 1. Some of potential resources and locations based on oceanographic and ecosystem divesity

\begin{tabular}{ll}
\hline Location & Uniqueness \\
\hline Dodola Island & Landscape view, ecosystem \\
Tanjung Gorango & Sharks, semi-enclosed water \\
Rao Island & Turtle, reefs, and seagrass \\
Kokoya Island & Snorkeling, diving, and beach activities \\
Koloray & Landscape view, ecosystem \\
Ngele-ngele & Aquaculture \\
Zumzum & Ecosystem biodiversity, historic place \\
\hline
\end{tabular}

Source: In-situ survey in 2015

These small islands also supported by several numbers of side infrastructures such as hotels, small ships, tour guide, homestay, halal food, dive center, and culinary. Based on data, there are around 29.000 tourists came to Morotai from January to March 2019. The tourists came to visit the historical place, snorkeling and diving, and culinary. For this potential area, the development must be improved. The ocean condition such as ocean currents and temperature fit with tourism activities. In the north side, the surfer uses high wave, meanwhile in the south side, tourists use calm water to snorkel and dive.

To develop Morotai in general has the aim by analyzing the ocean condition and utilizing the potential of the region to prosper the people in the region. Indonesia via the government mission, create tourism as an important role in economic growth (Rashid, 2019). Furthermore, the government must be ensuring that high biodiversity and ocean support could be raise the revenue from these aspects. OECD (2016) based on year 2010 estimated economic activities associated with the ocean amounted to around US\$1.5 trillion.

Revenue of regional government in Pulau Morotai consist of local revenue. (PAD) is pure income that obtained from region, meanwhile balance fund is transfer from central to region for denied different fiscal among region. In 2018, Morotai has a revenue $35.000,00$ million rupiah, a significant increase when compared to the previous year amounted to 7.538,51 million rupiah. Meanwhile, expenditure consists of expenditure not directly and indirectly. In 2018, the expenditures is 674.587,82 million rupiah an increase compared to the previous year of 759.792,05 million rupiah.

GDRP at current prices by business sector in 2018 amounted to $1.319,05$ billion rupiah. The share is still dominated by agricultural groups in the amount of 47,26 percent. Moreover, USAID (2017) has found that Morotai has abundant fisheries and marine resources and become one of the national priorities to accelerate economic growth from the fisheries sector. Based on fish-production estimations, Morotai contributes about 61,167 tons of fish per year.

The last is about global warming not only affected ecosystem health especially to coral bleaching but also fishery revenue. In Korea, revenue losses from tourism were estimated at \$29-37M USD (Jang, Hong, Lee, Lee, \& Shim, 2014). In the other case, The Great Barrier Reef in Australia has an economic asset value equal to $\$ 56$ billion. These areas of coral reefs support 64,000 jobs and contributes $\$ 6.4$ billion to the Australian economy (Deloitte Access Economics, 2017). 


\section{CONCLUSION AND RECOMMENDATION}

\section{Conclusion}

The location in the southern part is very suitable for marine culture and tourism, while in the northern region it is very suitable for tourism, conservancy, and fishing. The presence of endemic biota is a potential that can be developed as a tourist attraction. Walking sharks can only be found in two regions in Indonesia, one of this species can found in Morotai Islands. If the stakeholders can provide facilities and infrastructure and disseminate this as a special interest tour with the main object seeing the beauty of the underwater ecosystem and biota. This can become a new source of income and enhance Morotai's economy. The community is very supportive in developing this tourism for the economic growth of the community by facilitating access to the city. Therefore infrastructure development, especially road infrastructure is a very important development priority to be realized.

\section{Recommendation}

There are some policies recommendation that can be implemented in Morotai such as monitoring ecosystem health, ocean forecast, and fishery area. By monitoring the ocean character will be a guide to enhance the potential of natural resources. The government also has to sustain the area by making conservation area. Therefore, the government should focus on strengthening the information and systems. The challenge in Morotai are the infrastructure, awareness, education, and technology. In addition, the challenges that must be watched out from marine pollution include the oil spill by ships, because this region is also one of the ALKI line. Moreover, marine debris is national issue that led to aesthetic for tourism. This ocean garbage not only produce by local source, moreover comes from other countries. On the other hand, this region is also one part of the "ring of fire" in the Pacific route. Volcanoes that are under the sea and plate movements can cause earthquakes and tsunamis. Infrastructure development should consider this potential.

\section{ACKNOWLEDGMENTS}

We grateful to Ministry of Fishery and Marine Affairs (KKP) for supporting data. We also thank anonymous reviewers to enhance this paper.

\section{REFERENCES}

Ahmad, F. (2014). Jenis-jenis Bakau di Daruba dan Wayabula, Pulau Morotai, Maluku Utara. Berita Biologi, 13(3), 255-262.

BPS Morotai. (2019). Kabupaten Pulau Morotai dalam Angka. Pulau Morotai: BPS

Kabupaten Pulau Morotai

Deloitte Access Economics. (2017). At what price? The economic, social and icon value of the Great Barrier Reef. Brisbane: Deloitte Access Economics

DKEK. (2018). Kawasan Ekonomi Khusus Morotai. Available at: http://kek.go.id/kawasan/Morotai

Haikal, V.M., Taofiqurohman, A., \& Riyantini, I. (2012). Analisis Massa Air Di Perairan Maluku Utara. Jurnal Perikanan dan Kelautan, 3(1), 1-9.

Jang, Y. C., Hong, S., Lee, J., Lee, M. J., \& Shim, W. J. (2014). Estimation of lost tourism revenue in Geoje Island from the 2011 marine debris pollution event in South Korea. Mar. Pollut. Bull. 81(1), 49-54. https://doi.org/10.1016/ j.marpolbul.2014.02.021

KKP. (2015). Rencana Zonasi Wilayah Pesisir dan Pulau-Pulau Kecil. Jakarta: KKP 
Lana, A.B., Kurniawati, N., Purba, N.P. \& Syamsuddin, M.L. (2017). Thermocline Layers Depth and Thickness in Indonesian Waters when Southeast Monsoon. OmniAkuatika, 13(2), 65-72. http://dx.doi.org/10.20884/1.oa.2017.13.2.70

Nugraha A.P., Purba, N.P., Junianto \& Sunarto. (2019). Ocean Currents, Temperature, and Salinity at Raja Ampat Islands and The Boundaries Seas. World Scientific News, 110, 197-209.

Nurhayati. (2006). Distribusi Vertikal Suhu, Salinitas dan Arus di Perairan Morotai, Maluku Utara. Oseanografi dan Limnologi di Indonesia, 40, 29 - 41

Nurkholis, Nuryadin, D., Syaifudin, N., Handika, R., Setyobudi, R.H. \& Udjianto, D.W. (2015). The Economic of Marine Sector in Indonesia. Aquatic Procedia, 7, 181 186. https://doi.org/10.1016/j.aqpro.2016.07.025

OECD. (2016). The Ocean Economy in 2030. Paris: OECD Publishing.

Purba, N.P., Faizal, I., Pangestu, I.F., Mulyani, P.G. \& Fadhillah, M.F. (2018). Overview of physical oceanographic condition at Biawak Island: past achievement and future challenge. IOP Conf. Series: Earth and Environmental Science 176, 012001.

Purba, N.P., \& Pranowo, W.S. (2015). Dinamika Oseanografi Deskripsi Karakteristik Massa Air Dan Sirkulasi Laut. Bandung: UNPAD Press

Ramos, A., Purba, N.P., Mulyani, Y. \& Syamsuddin, M.L. (2018). Microplastic tracking from Pacific garbage to Northern Indonesia Sea. Jurnal Perspektif Pembiayaan dan Pembangunan Daerah, 6(1), 87-96. https://doi.org/10.22437/ppd.v6i1.5178

Rashid, I. (2019). Toward a tourism destination brand equity of coastal tourism of Pangandaran Regency. Jurnal Perspektif Pembiayaan dan Pembangunan Daerah, 7(2), 183-194. https://doi.org/10.22437/ppd.v7i2.7483

Sahidi, S., Sapsuha, G.D., Laitupa, A.F. \& Tangke, U. (2015). Hubungan faktor oseanografi dengan hasil tangkapan pelagis besar di perairan Batang Dua, Propinsi Maluku Utara. Agrikan: Jurnal Agribisnis Perikanan, 8(2), 53-63. https://doi.org/10.29239/j.agrikan.8.2.53-63

Schlitzer, R. (2018). Ocean Data View. Available at: https://odv.awi.de.

Simanjorang, J.E., Pranowo, W.S., Sari, L.P., Purba, N.P., \& Syamsuddin, M.L. (2018). Building up the database of the Level-2 Java Sea Ecoregion based on physical oceanographic parameters. IOP Conf. Series: Earth and Environmental Science 176, 012009.

USAID. (2017). Activity report: scoping study at Morotai islands in North Maluku. USAID sustainable ecosystems advanced (USAID SEA) project. Available at: http://www.sea-indonesia.org/wp-content/uploads/2017/07/SEA-Activity-ReportCTC-Scoping-Study-Morotai_19-26Feb17-Final-1.pdf 